\title{
ILCEA
}

Revue de l'Institut des langues et cultures

d'Europe, Amérique, Afrique, Asie et Australie

19 | 2014

Acceptabilité et transgression en langues et cultures de spécialité

\section{Blame It on the Bucky!: The Positioning of Buckfast Tonic Wine between Acceptability and Transgression}

"Blame it on the Bucky! » : le positionnement du vin tonique Buckfast entre acceptabilité et transgression

\section{David Leishman}

\section{OpenEdition}

Journals

\section{Electronic version}

URL: http://journals.openedition.org/ilcea/2412

DOI: $10.4000 /$ ilcea.2412

ISSN: 2101-0609

Publisher

UGA Éditions/Université Grenoble Alpes

\section{Printed version}

ISBN: 978-2-84310-280-6

ISSN: $1639-6073$

\section{Electronic reference}

David Leishman, "Blame It on the Bucky!: The Positioning of Buckfast Tonic Wine between

Acceptability and Transgression », ILCEA [Online], 19 | 2014, Online since 27 June 2014, connection on 24 April 2019. URL : http://journals.openedition.org/ilcea/2412 ; DOI : 10.4000/ilcea.2412

This text was automatically generated on 24 April 2019

(C) ILCEA 


\title{
Blame It on the Bucky!: The Positioning of Buckfast Tonic Wine between Acceptability and Transgression
}

\author{
"Blame it on the Bucky! »: le positionnement du vin tonique Buckfast entre \\ acceptabilité et transgression
}

David Leishman

1 In 1882, an order of Benedictine monks in Buckfast Abbey, Devon, began selling a tonic wine using imported wine to which a number of active ingredients were added. In 1927, following the loss of their commercial licence, the monks entered into a partnership with a newly created firm, J. Chandler \& Co. (Buckfast) Ltd. The monks of Buckfast Abbey were represented in the new venture by the Lord Abbott of Buckfast who was listed as a shareholding company director. The aim of the new company was "to carry on the business of dealers in and sole agents and distributors of a tonic wine, known as Buckfast Tonic Wine" ("New Companies", 1927).

2 Over the next few decades, Buckfast, now with a sweeter, more palatable recipe, became one of the best-known tonic wines on the market despite the absence of any active ingredients or health-giving properties (Cooper, 1970, pp. 216-8). Until the Trade Descriptions Act 1968 prohibited falsely describing a product's composition or "fitness for purpose", Buckfast Tonic Wine was advertised as a "quick acting and pleasant restorative", which, for example, could aid sufferers to "get rid of depression / lassitude / exhaustion" (1934) or allow "a new lease of life" for those who were "recovering from an illness" (1959). The strategy of distributing Buckfast Tonic Wine through chemists' nevertheless helped to maintain what Derek Cooper has described as its "spurious" medicinal image, helping people to associate its consumption with being "more able to resist disease", which meant that its sales were particularly strong in winter or when an outbreak of flu was reported (pp. 216-7). 
On the bottle's distinctive label the Abbey Church of St Mary is still figured today, along with a registered trademark (1927) featuring a bishop's mitre and crook. The commercial positioning of Buckfast Tonic Wine is therefore clearly one which links its original medicinal and restorative claims with the pious vocation of the Benedictine monks who produce it, thus creating a general aura of beneficence.

4 However, despite this connection with spirituality and health, epitomized in one 1971 ad which concluded that Buckfast Tonic Wine was "To make you feel better, be better", the product became increasingly associated with binge drinking in the North Lanarkshire area of Scotland from the 1980s onwards. The transgressive re-appropriation by predominantly young street drinkers of an alcoholic drink which supposedly targeted a middle-aged to elderly market with concerns for their health generated a wave of newspaper reports and political campaigns criticizing the drink known simply in the press as "Buckfast" or "Bucky". The debates concerning the responsibility of J. Chandler \& Co. (Buckfast) Ltd and the monks of Buckfast Abbey in the face of this phenomenon have often taken place directly in the media, with, in particular, sales director Jim Wilson and managing director Anthony Joyce regularly defending the product in letters, articles and interviews. The Benedictine monks, however, have been largely absent from the furore over the wine they produce, allowing the distribution firm to reply in their stead. The lack of response from the monks as regards the social repercussions of their commercial activities could seem to be the natural corollary of their discretion and monastic retreat. We can note, however, that a problematics of silence and absence is also central to the commercial positioning of the wine as its distributors attempt to navigate between the contradictory poles of acceptability and transgression.

\section{"A bottle of stab-yer-pal" Buckfast as a symbol of transgression}

The 1996 Food Labelling Restrictions specify under section 8 "Misleading Descriptions", that the term "tonic wine" can be only be used if placed in immediate proximity to the statement: "the name 'tonic wine' does not imply health giving or medicinal properties" ("Food Labelling Restrictions", 1996). This double play over the term "tonic" indicates a form of onomastic transgression whereby the wine's name simultaneously evokes and denies its medicinal properties. Similarly, the profusion of informal nicknames attributed to Buckfast Tonic Wine also indicates the transgressive nature of its reappropriation by young, socially marginalized drinkers in the North Lanarkshire region.

Such names include:

- A bottle of 30 days

- A bottle of fight-the-world

- A bottle of stab-yer-pal

- Brown Sauce

- Buckie Baracas

- Charge

- Coatbridge Table Wine

- Commotion Lotion

- Cumbernauld Rocket Fuel

- The Dark Destroyer 
- Lanarkshire Gravy

- Loopy Juice

- Magic in a Bottle

- Mrs Brown

- Wreck the hoose juice

7 The connotations of darkness, violence and transformative power are often in evidence, with one of the most common names "A bottle of 30 days" arising from the length of the custodial sentence that drinkers could reportedly expect following an offence committed under the influence of the drink. Several names evoke the three towns of North Lanarkshire presented as forming the "Buckfast Triangle", Coatbridge, Airdrie and Cumbernauld, where reports of the abusive consumption of Buckfast began to appear in the press in the early 1990s. Although not technically a fortified wine (Joyce, 2004), Buckfast is a relatively strong (15\%), sweet-tasting wine containing vanillin and had become extremely popular among young and underage drinkers who would consume the wine by the bottleful in outdoor locations, leading to a range of antisocial behaviour issues, from littering to stabbings involving broken Buckfast bottles. The drink itself has been glorified among young drinkers for the distinctive "buzz" accompanying its inebriating effect, which no doubt results from its high caffeine content.

8 The actual sales figures are contested by the distribution firm who have stated that Lanarkshire represents as little as $7 \%$ of the total sales of the drink ("The Monks' Tonic", 2006). As local campaigners have noted, the firm is reluctant to acknowledge the volume of Buckfast consumed in this area (Thomson, 2002), but earlier figures in the drinks industry trade press regularly stated that $80 \%$ of Buckfast's worldwide sales were achieved in this part of Central Scotland ("Hands Off", 1994). Despite the economic crisis, total sales of Buckfast have remained robust and have increased in recent years, with figures for 2011-2012 showing a turnover of £39m (Macdonald, 2013).

According to a 2010 "BBC Scotland Investigates" TV report, Buckfast is now "a by-word for irresponsible drinking" while Robert Young's study of antisocial youth subculture in Scotland reaffirmed the act of drinking Buckfast as the quintessential marker of "Ned" identity, (using the term commonly employed as a Scottish equivalent of "Chav" to indicate disaffected white youths). The connection between Buckfast and antisocial acts has been underlined by its mention in thousands of police crime reports in West Central Scotland where, more generally, excessive alcohol consumption is rife ("Police Reports", 2013). Six of the eight Scottish constituencies with the highest levels of alcohol-related mortality, are to be found within North Lanarkshire, with the constituency of "Coatbridge, Chryston \& Bellshill" being the worst in the UK (Robertson, 2012).

In the early 1990s, the first political campaigns addressing North Lanarkshire residents' concerns about Buckfast questioned how its commercialization could be limited (e.g. the adoption of a dissuasive pricing policy) or rendered less socially damaging (e.g. the introduction of plastic bottles.) These initiatives, led by North Lanarkshire MPs Tom Clarke (1992) and Helen Liddell (1994), were followed up by a number of other Scottish politicians who have sought to tackle the issue, such as Scottish Justice Minister Cathy Jamieson (2004), ${ }^{1}$ Scottish Health Minister Andy Kerr (2006), Euro MP Catherine Stihler $(2008,2010)$ and Richard Baker MSP (2010). These campaigns have often been relayed with a degree of support by Scottish and UK newspapers. In response there has been a vigorous campaign to defend the drink undertaken by the distributors J. Chandler \& Co. (Buckfast) Ltd. 
11 What is clear is that the product is now the focus for a set of contradictory discourses which define Buckfast Tonic Wine in a dialectic which opposes antisocial, abusive alcohol consumption on one hand, and, on the other, the eminently respectable values of health, heritage, moderation and piety. Buckfast as a media phenomenon exists because of its unstable positioning between these irreconcilable poles of transgression and acceptability. The rival discourses shall now be examined in detail.

\section{Made by monks, drunk by drunks²: discourse and counter-discourse on the acceptability of Buckfast Tonic Wine}

The articulation between acceptability and transgression has been rendered more acute by the religious origins of the product. As journalist Derek Cooper noted, Buckfast's 1970s advertising emphasized its "goodness", which was "not an unwise line to stress considering its impeccable religious connections" (p. 218). Today this spiritual dimension is central to the formulation of some criticism where binary structures are used to highlight a fundamental opposition between the drink's spiritual origins and its negative social impact: "Buckfast wine may be made by monks, but it's an evil drink for all that" ("A Fast Buck", 1995). Alternatively, the religious connection is used by defenders of the drink to mitigate criticism, or even to rationalize negative comments as a form of discrimination. According to one pronouncement by an Abbey spokesman: "We believe Buckfast is unfairly attacked by the media since it has a monastic background" (quoted in Wong, 1994).

13 The fundamental contradiction between moderation and debauchery, compassion and violence, good and evil, is thus taken up by both sides of the debate. Helen Liddell MP, one of the earliest campaigners, attempted to exploit a sense of spiritual obligation among the monks by providing them with a video which illustrated the social impact of their wine: "There is no doubt that the monks here are compassionate men. And I believe that no-one with any compassion could watch this video [of Buckfast drinking in N. Lanarkshire] and not be affected" ("Monks Defend", 1994). ${ }^{3}$ Taking this logic further, Liddell, a Roman Catholic herself, threatened to write to the Pope if the monks did not take action ("Threat to Call Pope", 1994) while the Reverend Bob Gillies, the Episcopalian Bishop of Aberdeen \& Orkney, has used his own religious position to condemn the monks' actions as fundamentally compromising their spiritual calling ("PM with Eddie Mair", 2010). Journalists quickly adopted the lexicon of the Bible and hymnary to present the controversy: "grapes of wrath" ("Abbey Rejects", 1994; "Liddell Tramples", 1994), "sin and tonic" (Storrar, 2005). In Alan MacDermid's article entitled "No Release for Family Trapped in Private Hell" (1992), which raises the question of the responsibility of the monks following a violent attack committed by an assailant who had consumed Buckfast, readers are invited to pray for the soul of the prior of Buckfast Abbey, who is likened to Pontius Pilate. This can be contrasted with Robert Hardman writing in the Daily Mail who exonerates the makers of Buckfast by stressing the monks' religious devotion, thus ridiculing any accusations of improper conduct by the claim that they embody a life of meekness, propriety and calm. Hardman's article presents the drink by means of an oxymoron-"evil elixir"-to better underline the absurdity of any social critique. 
In the BBC Scotland Investigation "The Buckfast Code" broadcast in 2010, the axiology of good versus evil is simply inverted, which highlights the tendency of Buckfast's distribution company to absolve the Abbey of any negative claim which may be made:

- Ken Macdonald (BBC): "So you don't think the monks should accept any kind of moral responsibility?"

- Jim Wilson, J. Chandler \& Co. (Buckfast) Ltd: "No. Why should they? They produce a good product. Buckfast is an exceptionally good product."

More prosaic arguments were, however, the principal focus for the first wave of criticism in the early 1990s which concentrated on the wine's relatively low price, the exclusive use of glass bottles, and its high alcohol content. In later years, attention also came to focus on its high caffeine content. From 2007 onwards, the issue of using glass bottles was given increased prominence once more following studies which emphasized the high percentage of broken glass from Buckfast bottles in certain N. Lanarkshire towns, and which reaffirmed the danger posed by broken Buckfast bottles in stabbing incidents (Adams, 2009; Forsyth \& Davidson, 2010, p. 79; Galloway, Forsyth \& Shewan, 2007, p. 4; Forsyth, Davidson \& Lennox, 2007, pp. 86-7).

To counter the argument concerning the sales price Buckfast has claimed that, contrary to some reports in the media, Buckfast is no cheaper than other alcoholic drinks of comparable strength (Joyce, 2001; Macdonell, 2006a) while the argument about replacing glass bottles with plastic ones has been opposed for ecological (Joyce, 2001) and economic reasons (Jim Wilson qtd in "The Buckfast Code", 2010). In the study by Galloway, Forsyth and Shewan, drinkers of Buckfast also voiced their opposition to such a change, citing the impact it would have on the taste (p. 86) as the wine is frequently drunk straight from the bottle, and, more cynically, noting that plastic bottles would make less effective weapons (p. 87). J. Chandler's strategy has also been to simply refute the evidence behind certain claims such as those affirming the danger of caffeinated alcohol drinks or the quantity of broken glass from Buckfast bottles as a percentage of total street detritus ("Hands Off", 1994). According to managing director Anthony Joyce, the alcohol content of Buckfast is "middle of the road" (qtd in "Hands Off", 1994), i.e. similar to or "only slightly stronger" (2001) than the other table wines with which it is categorized under the maximum of $15 \%$ by volume (2004). In order to argue its innocuity, a Buckfast spokesperson compares it favorably to whisky, which, as an emblematic Scottish product, enjoys positive cultural associations despite its high alcohol content and stronger sales (qtd in "Where does", 2005). When the radical solution, proposed by local residents or journalists, of a ban on the sale of Buckfast at least in certain areas has been put forward (Galloway, 2006; Gill, 1992), this has been strongly condemned as illegal by J. Chandler. Their argument, citing the Human Rights Act 1998 and European Community law regulating free trade, states that the law forbids any restrictive commercial measure which singles out a brand, rather than a category of drink (Watson, 2009; Jamieson “Letter from Angus G. MacLeod", 17 February 2005).

17 Another series of counter-arguments is based on the idea of a Scottish exceptionalism. These contrast the international presence and long history of the drink with the fact that criticisms and complaints have only appeared in recent years, and that these problems are exclusive to Central Scotland: "We have sold a product for more than 80 years in several different countries and nowhere else is anybody linking it to health or crime" (Jim Wilson qtd in Murray, 2010; Gray, 2010; Storrar, 2005). 
18 If J.Chandler seeks to foreground international sales of the drink, for example mentioning that it is popular in the Caribbean, Australia and even France (Hardman, 2010), it is clearly to render illegitimate the criticisms concerning problem drinkers in Scotland by insisting that these represent no more than a small, geographically circumscribed minority, exceptional in their misuse of the product: "The overwhelming majority of consumers worldwide drink Buckfast responsibly" (Joyce qtd in "Hands Off", 1994). When the drink is associated in this way with acceptable consumption, the responsible drinkers of Buckfast are figured as emblematic "elderly ladies" (Gill, 1992) or other eminent members of society who confer, once again, an image of moderation and respectability to the drink. By extension, to attack Buckfast by associating it with underage drinking, violence and social degradation is to sully the reputation of what is posited as a respectable majority of drinkers around the world and through the ages:

[M]alicious comments concerning Buckfast are hurtful to the thousands of "sane" people throughout Scotland who for many years have bought and consumed Buckfast as both a pleasant quality drink and a tonic-including the recent Lord Provost of the City of Edinburgh. My company has sold Buckfast world-wide for almost 80 years and it has been bought by generations of Scots throughout that time. (Joyce, 2003)

19 As Motherwell District councilor Richard Thomson noted, J. Chandler has been reluctant to provide the sales figures which would confirm the veracity of the international exception argument by showing that the Scottish market where problem drinking has become rife represents but a small minority of total global sales. J. Chandler spokespersons such as Aloysius Joyce have built on the geographic argument to suggest that the localized misuse, unknown in other parts of the world, must reveal underlying social issues which cannot be attributed to the drink itself: "[T]he only area that reports its abuse is a small part of Scotland. Are there perhaps some special problems in the area?" (Qtd in Arlidge, 1994; Wong, 1994) The distribution firm and Abbot David Charlesworth have, for example, underscored the social problems affecting North Lanarkshire such as its high level of unemployment (qtd in "Abbey Rejects", 1994). The criticism is thus deflected by stating that North Lanarkshire's social problems are due to politicians and the press, who are prompt to condemn Buckfast but who have failed in their own responsibilities (Anthony Joyce qtd in Murray, 2004; Macdonell, 2006b). Anthony Joyce of J. Chandler indicated in 2002 that while social conditions in the area are dire, journalists have played their part through their "unprofessional" coverage:

Perhaps it is time for The Herald to return to the great traditions of journalism and investigate the underlying causes of deprivation in towns such as Coatbridge instead of making unsupportable allegations against products such as Buckfast.

20 Taking this further still, Anthony Joyce claims that his firm, not the Government, has been taking the lead in implementing solutions: "The problem is essentially a social one and that is where the Scottish Executive should be directing its time, effort and moneyas my company has in support of numerous community-led initiatives in Scotland." (2003) The idea that Buckfast misuse is not the root cause of social problems but indicates an underlying set of issues is indeed corroborated by sociologists such as Robert Young, who has concluded that banning Buckfast would not be an effective solution (Young, 2012, p. 15).

21 J. Chandler spokesman Jim Wilson regularly claims that as Buckfast represents a very small share of the total alcoholic drinks market (the figure of 0.5 to $1 \%$ is given) any solution to problem-drinking has to be focused on an industry-wide approach: "You have 
to look at this in its entirety. We are a small part of a GBP 7 billion industry. We are less than 0.5 per cent of the total alcohol market." (Qtd in Macdonell 2006a; qtd in "Drinks firm warns", 2008; qtd in Wong, 1994) Whereas most of the criticism of Buckfast has come from Labour politicians, the SNP Government has acknowledged this last argument to some degree. In their drive to cut alcohol abuse they have been reluctant to focus on Buckfast as an isolated problem, despite some concerns regarding this brand, preferring instead to focus their efforts on introducing legislation which sets a minimum price for all alcoholic drinks (Murray, 2010). It has, however, been noted that the minimum pricing policy could actually result in making tonic wines comparatively more appealing to street drinkers in terms of price (Forsyth, Ellaway \& Davidson, 2014, p. 101).

The question of the individual responsibility of consumers is often invoked by J. Chandler as they attempt to counter claims that the manufacturers or distributors of Buckfast Tonic Wine should be called to account when Buckfast is associated with problem drinking: "The answer is not to blame any product but the individuals; they are the ones indulging in antisocial behaviour, not Buckfast." (Jim Wilson qtd in Macdonell, 2006b) This point is illustrated through a number of analogies offered by representatives of Buckfast where the tonic wine is replaced by alternative social ills: "It is completely wrong to blame the knife manufacturer if someone stabs someone. Why just attack Buckfast?" (qtd in Gray, 2010); "If a reckless driver crashes a fast car, do you ban the car or the driver?" (qtd in Hardman, 2010). From Anthony Joyce's perspective, the individuals involved in reprehensible behaviour are to blame, but they are being encouraged to avoid taking personal responsibility for their drug-taking, alcohol abuse, or violent acts by the media's focus on the role of the manufacturer: "[...] in this world of myths 'Buckie' has become the well-worn excuse for both an over-indulgence in all forms of alcohol and a cover-up for not admitting to mixing alcohol with illegal drugs" (2001). As this view is shared by Jim Wilson (qtd in "The Buckfast Code", 2010) it appears that J. Chandler considers the Scottish Government to be negligent for criticizing Buckfast instead of strongly reaffirming this message of individual, rather than corporate, responsibility:

I think the Scottish Executive are the ones who are not taking their duty seriously. [...] The message they are sending out is the wrong one. They are blaming the alcohol and the drugs, the message that should be going out is-if you commit a crime you will be dealt with by the law, and they are being very foolish in suggesting anything other than that. (Jim Wilson qtd in Macdonell, 2006b)

This discourse plays into the argument concerning the purported majority of respectable consumers of Buckfast. This has been voiced, for example, by Euro MP Ashley Fox who stated that those who freely choose to enjoy the drink would be punished because of the actions of "an ignorant few" if ever the drink were to be banned (Fox, 2010).

In the area of corporate responsibility, as in others, the spokespersons of J. Chandler \& Co. (Buckfast) Ltd, and their occasional supporters in the press, have shown a tendency to engage in reductio ad absurdum arguments in their deflection of criticism. It has been argued, for example, that the manufacturers cannot be responsible for the nuisance associated with Buckfast Tonic Wine because managing director Anthony Joyce does not himself break bottles in the street (McNicol, 2001), nor do the monks of Buckfast Abbey pour the wine down people's throats (qtd in Gray, 2010). On the subject of broken glass, $\mathrm{J}$. Chandler makes use of a similar argument which concludes that it is illegitimate to ask Buckfast to adopt plastic bottles unless all glass bottles containing alcohol are targeted (qtd in Adams, 2009). Anthony Joyce similarly observed that: "If [campaigner MP Helen] Liddell is so concerned about promoting public health, she should logically move to ban 
all types of alcohol" (qtd in Murray, 2004). Proposals to modify the commercialization or composition of Buckfast are thus presented as measures which would, for reasons of fairness and equity, lead to widespread restrictions and blanket bans. As such, images of over-zealous politicians turning on other well known drinks are ironically evoked. When Buckfast's caffeine content became the focus for political debate, Jim Wilson wondered if the politicians would then "ban rum and Coke" as a logical extension (qtd in Hardman, 2010), whereas Anthony Joyce wondered if the press wished to ban cider, beer, vodka and "alco-pops" given that they all represented a larger percentage of the alcohol market than Buckfast (2003).

The systematic nature of J.Chandler's refutations has led them to rationalize the persistence of negative views of their drink by ascribing them to some other, illegitimate, motivation. Their line of defence implies that, in the absence of any basis in fact, requests for change can be rejected as a mere "whim" (Jim Wilson qtd in "The Buckfast Code", 2010), while criticism is just "cheap remarks" (Anthony Joyce qtd in Murray, 2004). In a BBC TV report Jim Wilson affirms that social scientists and other agencies ignore the vast majority of the alcohol market and choose instead to focus on Buckfast in order to please their "political Lords and Masters". This investigation was broadcast under the title "The Buckfast Code" and used imagery suggestive of Dan Brown's The Da Vinci Code (2003) in order to suggest that the manufacturer's arguments flirt with conspiracy theory. With any valid, evidential grounding denied, the regular criticism directed at Buckfast is claimed by the firm's representatives to reveal that the drink has become an unacceptable "scapegoat" and that a "vendetta against one particular product in one area surely displays prejudice bordering on paranoia" (qtd in Arlidge, 1994; qtd in Murray, 2004). It is the alleged transgression of media critics and social campaigners which is an unacceptable "scurrilous attack" (Joyce, 2002) and such behaviour is painted as vindictive, unjust and potentially mentally unstable. This defence is built around the central element of J.Chandler's justification which claims that the Abbey and their distribution firm are unimpeachable owing to the discretion they exercise in their commercial strategy. In particular, the monastic values of retreat, moderation and silence are invoked to depict the manufacturers' and distributors' uniquely responsible approach.

\section{Silence and the promotion of Buckfast}

A problematics of silence and discretion is suggested by the monastic production and the separation between manufacturing and commercialization that has existed since the creation of J. Chandler \& Co. (Buckfast) Ltd in 1927. By being largely disconnected from marketing and distribution roles, the Abbey may be seen as lending a positive image to the origins of the wine without besmirching its reputation through too visible a role in the commercial side of the venture.

27 Close ties with the commercial structure do exist, however. According to the Buckfast Abbey Trust Annual Report 2012, the monks produce the wine as Dart Abbey Enterprises Ltd, a subsidiary of their charity, Buckfast Abbey Trust (p. 2). Dart Abbey Enterprises sell the wine to J. Chandler \& Co. (Buckfast) Ltd with the proceeds made by Dart Abbey being returned to Buckfast Abbey Trust as a charitable donation. Buckfast Abbey Trust also owns $32 \%$ of the capital of J. Chandler \& Co. (Buckfast) Ltd (p. 23), and the Abbey Trust receives a royalty on each litre sold by J. Chandler (p.5). Despite being shareholders, the 
monks' objective is not to exert significant commercial control over the day-to-day operations however (p.23), and it can be noted that the while the monks have occasionally made statements in the press (Hardman, 2010; Bowditch, 1994), they typically allow J. Chandler to speak for them. More specifically, the firm's vocal defense of the Tonic Wine has included a plea that the monks should not become the focus of media attention ("Hands Off", 1994). While the Abbey Trust specifies in its annual report that it strives to be an ethical investor (p. 7), they have been criticized by Helen Liddell not simply because of their production of tonic wine, but because of their subsequent disengagement and refusal to acknowledge the social impact of the flagship product (qtd in Macdonald, 2010). Following her dealings with the monks, Liddell, in correspondence with the author, nevertheless described distributor J. Chandler as the main obstacle to progress.

J. Chandler's forthright attempts to defend Buckfast have involved several incidents where they have threatened legal action (Jamieson, 2005; McLaughlin, 2013; Watson, 2009) against what are perceived as scurrilous attacks on their product, such as a Strathclyde Police scheme to introduce anti-crime labels on bottles which can be traced back to the retailer in the event of an incident. Politicians who have been threatened with legal action for targeting Buckfast by name have rejected this as a form of intimidation. Minister of Justice Cathy Jamieson, who met with local retailers to discuss limiting the sale of Buckfast after meeting with residents, reaffirmed her right to voice the concerns of their constituents: "I take my responsibilities as a constituency MSP very seriously and I trust that [...] your clients are not suggesting that they would wish to stop an elected member from properly representing her constituents' views" (Jamieson, letter dated 3 March 2005). Richard Baker MSP similarly spoke of his refusal to be silenced when faced with a threat of legal action from solicitors representing J. Chandler in 2011 (qtd in Aitken, 2011). Politicians are also paradoxically criticized by J. Chandler for not speaking out. When Helen Liddell, responsible for one of the earliest campaigns in 1994, came to the forefront again in 2010, J. Chandler sought to ridicule her renewed criticism by questioning her supposed silence during the intervening period (Jim Wilson qtd in Macdonald, 2010). ${ }^{4}$ More significantly, J. Chandler has regularly suggested that its critics would be better advised to keep quiet owing to the counter-productive nature of the attacks, which allegedly results in each hostile political or media campaign being followed by a surge in sales: "The astonishing result is that the rather sluggish sales of Buckfast have grown in direct proportion to the comments in the media" (Anthony Joyce qtd in "Hands Off", 1994; "Buckfast Sales Surge", 2005). This leads managing director Anthony Joyce to wonder whether it is not the "constant peddling of 'Buckie myths' in the media" which is responsible for the drink's commercial success (2001).

Joyce's observations about his product's surprisingly robust sales are linked to his firm's central argument about corporate responsibility which has been repeated incessantly since the 1990s. "The monks of Buckfast take a very responsible attitude and this is reflected in the marketing policy of J. Chandler \& Co. The product is not promoted or advertised. If it were the property of any other brewery it would be ruthlessly exploited" (qtd in Wong, 1994; see also "Monks Defend", 1994; Joyce, 2001; Joyce, 2003; "Minister Meets", 2006). J. Chandler implies that this silence in terms of marketing communications is an active response to the criticism (whose validity it nonetheless disputes):

We are a responsible company. If [Helen Liddell] is saying we don't care or we don't listen, why is it that we have never advertised or promoted the product in 
Scotland? We couldn't have done any more than we have done. (Jim Wilson qtd in Macdonald, 2010) attitude of the distribution firm it nevertheless has the effect of creating a commercial absence, a semiotic void, which, for more mainstream products, is filled by advertising and point-of-sales promotional material. Rather than helping to minimize the abuse of Buckfast, it has been argued that this absence helps to position the drink as a product on the fringes of the alcohol market. Going further, it has been noted that Buckfast's mode of communication-notoriety garnered through word of mouth in the absence of any official advertising-creates an analogy with illicit drugs (Galloway, Forsyth \& Shewan, 2007, p. 7). When young, male Scottish street drinkers were surveyed about the alcoholic drinks available, this research showed that they perceived advertised brands as having a more feminine, emasculated image which discouraged their consumption of these products (p. 62). As such, Buckfast's lack of advertising, rather than discouraging purchase among a vulnerable population, could actually be having the opposite effect. It is particularly in the context of this absence of advertising that media campaigns and retailers' attempts to limit its consumption-for example, by only stocking the drink under the counter or limiting the number of bottles per sale (p. 106)-reinforce the image of a problem drink, destined for those who live "on the wrong side of the tracks" (p. 69). generate the extremely high level of brand awareness in North Lanarkshire even among young children, positing that the large quantities of discarded and broken Buckfast bottles in litter could represent an effective form of free advertising (Forsyth, Davidson \& Lennox, 2007, p.56). Today, more readily acknowledged forms of viral marketing impacting young people are constituted by social networks, video sharing sites and blogs which celebrate Buckfast, often by glamorizing an immoderate consumption of the wine (Galloway, Forsyth \& Shewan, 2007, p. 7). It is possible, for example, to view countless YouTube videos of drinkers performing the "Buckfast Challenge" which involves consuming a bottle of Buckfast as quickly as possible. Numerous but ephemeral Facebook or Bebo fan pages exist with titles such as "buckfast appreciation society" or "Drinking buckfast in the park because you're a classy cunt"5. Despite their transgressive, uncontrollable nature and coarse content, web pages such as these can represent a significant commercial benefit as consumers become "unofficial brand ambassadors" who endorse and market the product as effectively as official marketing campaigns (Leyshon, 2011, p. 22). Indeed, it can be argued that viral marketing of this sort allows the product to be promoted in ways that are quite simply impossible in a formal campaign. Whereas a strict industry code of conduct exists for the online promotion of alcoholic drinks, banning practices such as the promotion of excessive drinking or the targeting of youngsters (Committee of Advertising Practice, 2010, pp. 84-5), this only concerns official promotional content. User-generated Buckfast web content featuring fictional characters and personalities such as Ronald McDonald, SpongeBob, Homer Simpson or Andy Murray manifestly appeal to younger drinkers. It is also easy to find unofficial content which glorifies the violence associated with Buckfast, such as T-shirts with the slogan "Bed and Buckfast" above a pair of handcuffs, or images with slogans such as "Drink Bucky and Kill Cunts".

It has been noted that action by alcohol producers and social networks alike is necessary to dissuade unofficial online promotions involving unauthorized use of corporate logos or 
excessive consumption (Leyshon, 2011, p. 10). For J. Chandler this appears all the more necessary, as their silence in terms of traditional advertising means that such unconventional images and discourses today dominate the online and wider social positioning of Buckfast. While the Portman Group industry body advises alcohol producers to be watchful of such online misuse of corporate logos online, Alcohol Concern notes that "it is questionable to what extent this happens in practice" (ibid.).

Rather than appearing as the ultimate proof of J. Chandler \& Co. (Buckfast) Ltd's claim to be "the most responsible drinks manufacturer in Britain" (Jim Wilson qtd in Johnston, 2006) their silence in terms of traditional advertising and promotions may be taken as a key element in an unofficial, unacknowledged positioning as a transgressive product. This process has gained new intensity with the proliferation of user-generated content on the internet which now fills the void. While the firm frequently commends itself for not advertising Buckfast, this absence could actually serve to reinforce the drink's notoriety.

\section{Conclusion}

Rather paradoxically, J. Chandler \& Co. (Buckfast) Ltd refuses to recognize any inherent problems with its Tonic Wine while simultaneously presenting the absence of advertising as proof of its commercial virtue. They view any association of their product with transgressive behavior as unacceptable and counter that the responsibility for any related social ills lies elsewhere: with the consumer who should not abuse the product; with the Scottish Government which should deal with the industry as a whole; with local politicians who should tackle the grave socioeconomic issues in North Lanarkshire; with the media which should avoid spreading "Buckfast myths" which do nothing but increase sales for the drink.

Marketing specialists have nevertheless underlined that Buckfast's poor brand image is today indelibly associated with transgressive behavior. It was suggested in the journal Marketing that in order to change this image it would be necessary for J. Chandler to end its policy of systematic negation of Buckfast's role in problem drinking and become involved in a local campaign to change consumption habits. To this end, the monks themselves should end their customary silence and become active brand ambassadors of the drink, personifying an alternative, pious image of the drink that would counter that of violence and street drinking (Charles, 2010). We may wonder whether J. Chandler could not go further and re-introduce advertising of a similar form to that which existed until the 1970s. While unable today to feature the unsubstantiated health messages it once did, such advertising could, as before, evoke the Benedictine heritage and feature historical and monastic imagery to target the elderly, pious, moderate drinkers who are supposedly the drink's core market. The distributors of Buckfast could also remind consumers of their ties with their sister company, J. Chandler \& Co. Ltd, also founded in the 1920s and run by the Joyce family, who advertise themselves in The Tablet as a "long-established Catholic family firm of wine merchants specializing in the supply of Altar Wines to the Clergy and Convents". Advertising of this sort would actively counter the proliferation of user-generated images of excess and allow J. Chandler \& Co. (Buckfast) Ltd to reposition the tonic wine so as to render it less appealing to Scottish youths. The introduction of advertising in this way would certainly be acceptable in moral terms if it aimed at lessening the excessive consumption among vulnerable drinkers and refocusing on a more responsible target market. One problem remains, however. Given that street 
drinkers regularly consume one or more bottles of the tonic wine at a single sitting, ads which renewed a message of moderate consumption-by the glassful-could mechanically lead to a drop in sales in the key market of Central Scotland. Would such a strategy ever be commercially acceptable?

\section{BIBLIOGRAPHY}

“Abbey Rejects Politician's Grapes of Wrath”, Reuters, 15 November 1994.

ADAMS Lucy, "Plastic Plea to Buckfast over Bottle Attacks", Herald, 15 November 2009.

“A Fast Buck Saves Lives”, Daily Record, 17 August 1995.

AITKEN Mark, “Legal Threat to MSP Who Spoke Out about Buckfast's Link to Violent Neds”, Daily Record, 17 April 2011.

ARLIDGE John, “Tonic Wine Blamed for ‘Ruining Lives”, Independent, 22 August 1994.

"BBC Scotland Investigation Discloses Buckfast is Cited in Thousands of Police Force's Crime Reports”, [BBC Press Release], 18 January 2010, <www.bbc.co.uk/pressoffice/pressreleases/ stories/2010/01_january/18/code.shtml>.

воWDITCH Gillian, “Monks Dispute Earthly Effect of a Wee Buckie”, Times, 15 November 1994.

Buckfast Abbey Trust, Annual Report Year Ended 31 October 2012, 2012.

“Buckfast Sales Surge after Jamieson Appeal for Ban”, Scotsman, 8 May 2005.

Buckfast Tonic Wine Advertisement, Nottingham Evening Post, 3 December 1934.

-, Catholic Herald, 18 September 1959.

-, Catholic Herald, 22 October 1971.

CHARLES Gemma, “Buckfast Tonic Wine”, Marketing, 17 February 2010.

Committee of Advertising Practice, The CAP Code: UK Code of Non-Broadcast Advertising, Sales Promotion and Direct Marketing, Norwich, The Stationery Office, 2010.

COOPER Derek, The Beverage Report, London, Routledge \& Kegan Paul, 1970.

“Drinks Firm Warns Justice Minister over Slur on Buckie”, STV News, 4 November 2008, <http:// news.stv.tv/north/37767-drinks-firm-warns-justice-minister-over-slur-on-buckie/>.

Food Labelling Restrictions, Statutory Instrument 1996, No. 1499, 1996.

FORSYTH Alasdair J. M., DAVIDSON Neil \& LENNOX Jemma C., "An Investigation into the Environmental Impact of Off-License Premises on Residential Neighbourhoods", Glasgow Centre for the Study of Violence, November 2007.

FORSYTH Alasdair J. M. \& DAVIDSON Neil, “The Nature and Extent of Illegal Drug and AlcoholRelated Litter in Scottish Social Housing Community: A Photographic Investigation", Addiction Research and Theory, Vol. 18, No. 1, February 2010, pp. 71-83. 
FORSYTH Alasdair J. M., EllaWAy Anne \& DAVIDSON Neil, "How Might the Alcohol Minimum Unit Pricing (MUP) Impact upon Local off-Sales Shops and the Communities Which They Serve?", Alcohol and Alcoholism, Vol. 49, No. 1, 2014, pp. 96-102.

Fox Ashley, "One Minute Speech", Debates of the European Parliament, 8 March 2010. < www.europarl.europa.eu/RegData/seance_pleniere/compte_rendu/traduit/2010/03-08/P7_CRE (2010)03-08_EN.pdf>.

GALLOWAY Josie, FORSYTH Alasdair \& SHEWAN David, “Young People's Street Drinking Behaviour: Investigating the Influence of Marketing \& Subculture", Glasgow Centre for the Study of Violence, February 2007.

GaLloway Robin, “Buckfast: Opinion”, The Sun, 3 November 2006.

GILL Kerry, “Parents Seek Ban on Abbey Wine with a Blast Effect”, Times, 11 May 1992.

GRAY Rebecca, “Buckfast Cited by Strathclyde Police in 5000 crimes”, Herald, 17 January 2010.

"Hands Off the Monks' Plea from Tonic Wine Firm”, Off Licence News, 24 November 1994.

HARDMAN Robert, “Don't Blame the Monks for the Drunks”, Daily Mail, 23 January 2010.

J. Chandler \& Co. Advertisement, The Tablet, 4 January 2014, p. 19, <www.thetablet.co.uk/ viewpdf/19_Tablet_4_Jan_14.pdf>.

JAMIESON Cathy, Scottish Executive Correspondence File, [Letters dated 22 November 2004 to 15 March 2005], 2005, <www.scotland.gov.uk/Resource/Doc/1066/0011297.pdf>.

JoHnston Jennifer, “Buckfast: We're the Most Responsible Drinks Manufacturer in Britain", Sunday Herald, 15 October 2006.

JOYCE Anthony, “I Am Amazed that People ..." [Letter to the editor], Herald, 15 December 2001.

-, "Buckfast in Coatrbidge" [Letter to the editor], Herald, 5 December 2002.

-, “Sobering Facts about Buckfast" [Letter to the editor], Scotsman, 18 July 2003.

_, "Buckfast Defended" [Letter to the editor], Herald, 12 May 2004.

LEYSHON Mark, "New Media, New Problem? Alcohol, Young People and the Internet", Alcohol Concern, 2011.

“Liddell Tramples the Grapes of Wrath", Sunday Times, 20 November 1994.

LIDDELL Helen, “RE: Buckfast Meetings 1994", [Email to the author], 19 April 2012.

MACDERMID Alan, “No Release for Family Trapped in Private Hell”, Glasgow Herald, 13 November 1992.

MACDONALD Stuart, "Labour Peer Helen Liddell in Fresh Blast at Makers of Buckfast", Daily Record, 12 July 2010.

-, “Sales of Buckfast Jump Despite the Economic Downturn”, Daily Record, 25 January 2013.

MACDONELL Hamish, “Executive Accused of Turning Buckfast into a 'Cult' Drink for Young People”, Scotsman, 31 October 2006(a).

-, "McConnell Joins the War of Words on Buckfast", Scotsman, 20 November 2006(b).

MCLAUGHLIN Martyn, "Buckfast Tonic Wine Takes Police Force to Court", Scotsman, 23 February 2013. 
MCNICOL Douglas, “Don't Blame Buckfast, Blame Its Consumers" [Letter to the editor], Herald, 21 December 2001.

"Minister Meets Buckfast Company", BBC News, 30 October 2006, <http://news.bbc.co.uk/2/hi/ uk_news/scotland/6095474.stm>.

“Monks Asked to Stop Making Tonic Wine”, Glasgow Herald, 30 June 1994.

“Monks Defend Abbey Drinking Habit”, Glasgow Herald, 15 November 1994.

MURRAY Paula, “Stop Your Whining Liddell”, Daily Record, 20 May 2004.

_, "Commission Out to Target Buckfast Ban", Express on Sunday, 7 February 2010.

“New Companies”, The Western Morning News and Mercury, 25 May 1927.

PM with Eddie Mair [BBC Radio 4 Broadcast], Presenter Eddie Mair, 18 January 2010.

“Police Reports Link Buckfast Tonic Wine to Thousands of Offences”, Herald, 4 May 2013.

ROBERTSON Gordon, “Drink-Related Death Figures Shame Monklands”, Airdrie \& Coatbridge Advertiser, 14 March 2012, <www.acadvertiser.co.uk/lanarkshire-news/local-news/monklandsnews/2012/03/14/drink-related-death-figures-shame-monklands-65864-30525377/>.

STORRAR Krissy, "Sin and Tonic”, Mirror, 12 February 2005.

“The Buckfast Code", BBC Scotland Investigates [BBC One Scotland Television Broadcast], Presenter Ken Macdonald, 18 January 2010.

“The Monks' Tonic that Threatens to Seduce a Generation of Scots”, Scotsman, 30 October 2006. THOMSON Richard, "40 Years of Witnessing Havoc of Buckfast" [Letter to the editor], Herald, 18 December 2001.

_, "The Best Area for Buckfast Sales” [Letter to the editor], Herald, 7 December 2002.

“Threat to Call Pope into Tonic Wine Row”, Off Licence News, 17 November 1994.

WATSON Derek, “Buckfast Bosses Vow to Fight ‘Ban' on Controversial Drink”, Daily Express, 9 March 2009.

“Where Does the Buckfast Stop?", Off Licence News, 25 mars 2005.

"Where the Buck Stops", Times, 15 November 1994.

WONG Walim, "Passing Bucky on Issue of Trust is Out”, Western Morning News, 15 November 1994.

Young Robert, "Can Neds (or Chavs) Be Non-Delinquent, Educated or Even Middle Class? Contrasting Empirical Findings with Cultural Stereotypes”, Sociology, 10 September 2012, <http:// soc.sagepub.com/content/early/2012/09/10/0038038511435059>.

\section{NOTES}

1. Jamieson nevertheless made it clear that she was speaking out as an MSP and not as a Scottish government minister. See her letter dated 3 March 2005.

2. This slogan comes from a social network page set up to celebrate the consumption of Buckfast Tonic Wine: <http://archive.bebo.com/Profile.jsp?MemberId=1945897365>.

3. The same year, Richard Thomson, a Motherwell District councillor, adopted a similar approach (Arlidge).

4. This criticism ignores Liddell's comments made in 2004. 
5. Consulted October 2013, the page showed 13,607 "likes" although it has since been removed from Facebook.

\section{ABSTRACTS}

Commercialised as a product made by the Benedictine monks of Buckfast Abbey, Buckfast Tonic Wine adds an image of piety to the medicinal argument suggested by the legally authorized mention "tonic wine" and by its former mode of distribution in chemist's shops. However, despite this highly respectable dual connotation of health and spirituality, Buckfast has become the drink of choice for disaffected youths in Central Scotland, and Buckfast consumption has become associated with anti-social street drinking and violence since the 1990s. In order to contrast the criticism linked to the product's transgressive re-appropriation with the vigorous defence of the product offered by the manufacturers, we shall examine the discourses which have informed the debate. In reaction to the youths who vaunt the tonic wine or the politicians who have sought to limit its impact, the monks have remained largely silent in recent years. Instead, the notion of the acceptability of Buckfast is promoted via the press by J. Chandler \& Co. (Buckfast) Ltd, the independent firm which markets and distributes the drink. In particular, its representatives highlight the absence of any advertising, which is presented as proof of the corporate responsibility of Buckfast's producers and distributors.

Commercialisé comme un produit issu du travail de moines bénédictins, le vin tonique de l'abbaye de Buckfast en Angleterre porte le nom d'un lieu spirituel et associe ainsi des images de piété à l'argument médicinal suggéré par la mention d'un vin «tonique » et par sa distribution traditionnelle en pharmacie. Cependant, malgré la double connotation hautement respectable de santé et de sainteté, le Buckfast est devenue la boisson de choix parmi la jeunesse désœuvrée écossaise et sa consommation abusive est régulièrement impliquée depuis le début des années 1990 dans des actes de violence. À partir de ce constat d'un décalage radical entre l'image de marque vertueuse proposée par un produit et le détournement socialement préjudiciable de ce dernier par une population très éloignée de sa cible traditionnelle, nous examinons les discours des différents acteurs concernant l'acceptabilité de cette boisson. Face aux jeunes qui la revendiquent comme un produit qui rend non seulement ivre mais aussi agressif, face aux hommes politiques qui tentent de faire encadrer sa vente en Écosse, les moines producteurs restent largement silencieux. En l'absence de tout discours publicitaire, absence imputée à la retenue dont feraient preuve les moines, il revient à l'entreprise commerciale indépendante chargée de sa commercialisation de défendre, par voie de presse, l'acceptabilité du vin tonique Buckfast.

\section{INDEX}

Keywords: corporate discourse, media discourse, Buckfast tonic wine, Scotland, Ned, advertising, acceptability, transgression, street drinking, alcohol

Mots-clés: discours commercial, discours médiatique, vin tonique Buckfast, publicité, acceptabilité, transgression, consommation abusive, alcool 
AUTHOR

DAVID LEISHMAN

Université Grenoble Alpes (France) 